Reprod. Nutr. Dévelop., 1980, 20 (3 A), 681-685.

\title{
Ovarian meiotic prophase and the fetal pituitary in the rat
}

\author{
par A. GIROUD †, C. ROUX, Rolande DUPUIS, Cécilia HORVATH \\ Laboratoire d'Embryologie, Faculté de Médecine Saint-Antoine \\ 27, rue Chaligny, 75571 Paris Cedex 12
}

Summary. This report studies the ovaries of rat fetuses with hypophyseal agenesis provoked by an inhibitor of cholesterol synthesis. The gonads were compared morphologically to those of controls. It is concluded that the pituitary is not necessary for normal ovarian development in rats.

\section{Introduction.}

The meiotic prophase in the ovaries of most mammals occurs during the fetal stage. In spite of data on the role of the mesonephros in the onset of meiosis (Byskov, 1974), we do not know how it is triggered.

One hypothesis may be the intervention of the pituitary. We thus decided to examine the ovaries of fetuses with hypophyseal agenesis; these ovaries were obtained in studies on teratogenesis. Fetuses afflicted with holoprosencephaly, including varying degrees of such malformations as pituitary agenesis, cyclocephaly, cyclopia and monorhinia, can be obtained by administering triparanol or AY 9944 which inhibits cholesterol synthesis. A large number of fetuses have a minor form of holoprosencephaly, i.e. limited to isolated hypophyseal agenesis. We used these fetuses for gonadal study.

\section{Material and methods.}

Sixty-four Sprague-Dawley female rats, weighing $200 \mathrm{~g}$, were mated with males of the same strain. The day on which mating was confirmed by vaginal smear was day 1. The pregnant females were given AY $9944(100 \mathrm{mg} / \mathrm{kg} /$ day $)$ on days 2,3 , and 4 ; they were killed on day 21. The implantation sites were counted, and the fetuses were taken for study. After fixation in Bouin, they were examined for internal malformations. The body was dissected under a binocular lens.

A total of 282 live fetuses was studied. Holoprosencephaly was exteriorly visible in 65 (23 p. 100). The heads of 17 of the 217 apparently normal fetuses were histologically studied on $5 \mu$ serial sections; 14 of them or 82 p. 100 showed total hypophyseal agenesis. No pituitary tissue was found, even in ectopic position. The apparently normal heads of the 200 other fetuses were examined under a binocular lens 
according to the method of Wilson; isolated hypophyseal agenesis was found in 140 (70 p. 100). The difference with the heads on the serial sections was not significant with the $\chi^{2}$ test. The $5 \mu$ serial sections of the ovaries of 10 fetuses presenting hypophyseal agenesis were stained with ferric hematoxylin and compared to the ovaries of 5 control fetuses prepared in the same way.

Ovarian volume was estimated by the point counting grid of Weibel. Using a grid reticle, the oocytes on every 10 th section (about 10 counts per ovary) were counted on a field including the whole reticle and the ovarian tissue between the cortex and the hilus. The mean number of oocytes per field were then calculated for each ovary.

\section{Results.}

The ovaries of fetuses with hypophyseal agenesis were comparable in all respects with fetal control ovaries (fig. 1). In estimating their size, overall fetal hypotrophy had to be considered ; thus, the mean weight of a fetus treated on day 21 was $2.83 \mathrm{~g}$, while that of a control fetus was $3.42 \mathrm{~g}$ (or a ratio of 0.83 ). Since the ovaries could not be weighed before they were cut into serial sections, we measured their volume. The mean ovarian volume of the treated rats was $0.075 \mathrm{~mm}^{3}$, while that of the controls was $0.096 \mathrm{~mm}^{3}$ (or a ratio of 0.78 ). This volume ratio was comparable to the weight ratio, and indicated that, fetal hypotrophy taken into account, there was no ovarian hypoplasia in the treated rats.

Oocyte density was normal. The mean number of oocytes per field was $107 \pm 2.5$ in treated rats and $110+8.5$ in the controls. Student's and Wilcoxon's tests showed no significant difference. The oocytes of treated rats showed the same stages of meiotic prophase (prepachytene and pachylene) as the controls (fig. 1).

\section{Discussion.}

The mechanisms controlling meiosis are still not clear.

Byskov (1979) believes that meiosis is regulated by two antagonists : meiosisinducing substance (MIS) and meiosis-preventing substance (MPS). It is the balance of these two substances, varying in time, which would determine the chronology of meiosis, but the mechanism triggering it is a mystery.

Although a preleptotene stage is observed in the male fetuses of some species as man (Luciani et al., 1977), complete meiosis only appears at puberty. This leads us to wonder if the pituitary gonadotropins do not play a role.

Could the fetal pituitary be implicated in triggering meiosis in the female?

The fetal pituitary is certainly functional, but its functioning may differ, depending on the hormones and the species. Using immunofluorescence, Dubois and Mauléon (1969) showed LH activity in cells of the anterior pituitary in fetal sheep. Sano and Sasaki (1969) morphologically identified FSH and LH-like cells in the mouse at day 16. Schechter (1971), using the same method, found gonadotropic cells in the rabbit fetus at 19 days. In the human fetus, Bugnon ef al. (1976), using immunocytological techniques, showed the presence of LH and FSH subunits in the fetal anterior pituitary at week 15. Setalo and Nakane (1972), doing a cyto-immunochemical study, 

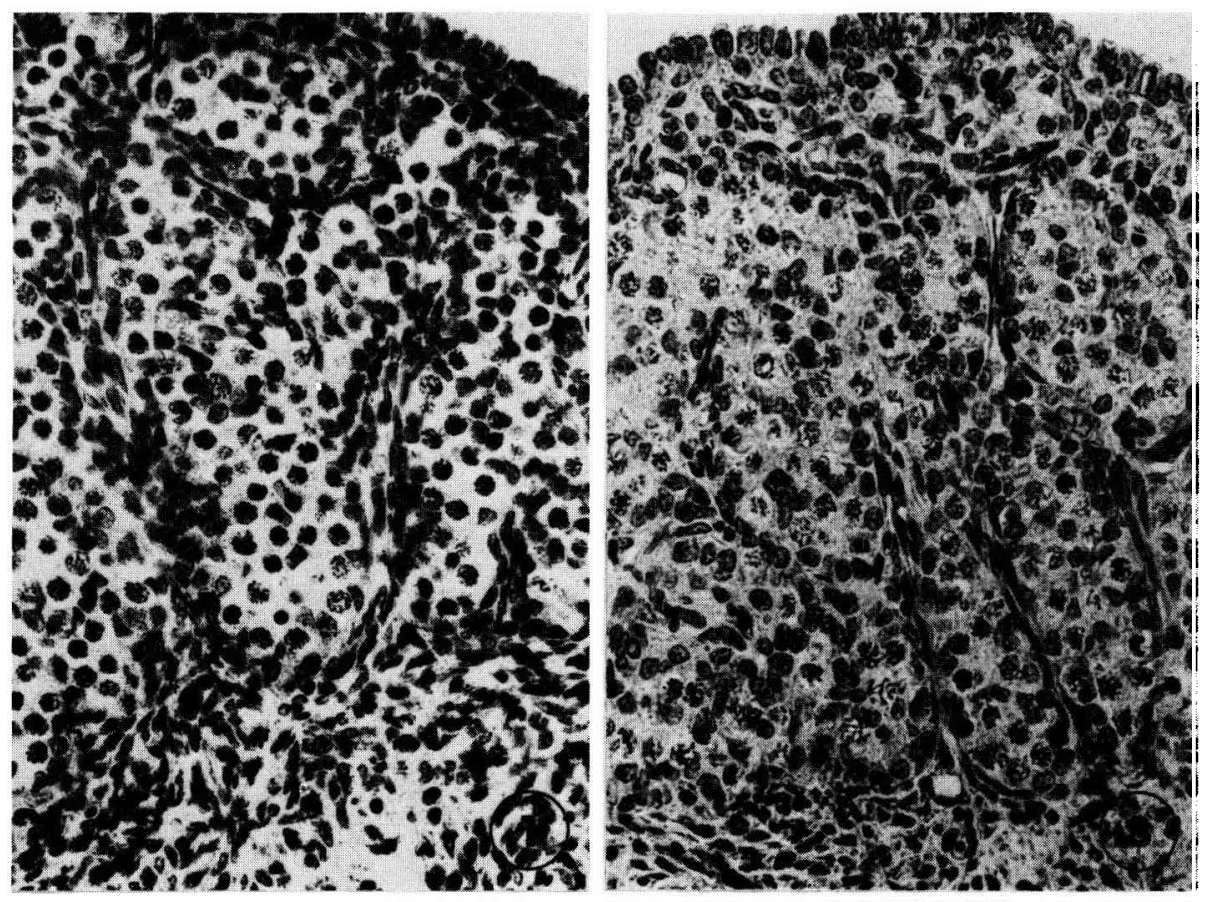

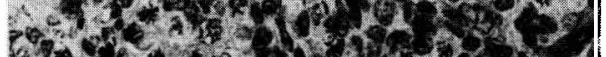

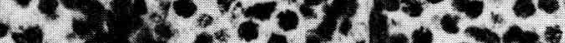

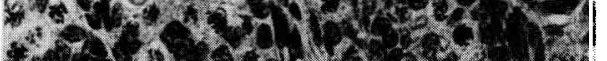

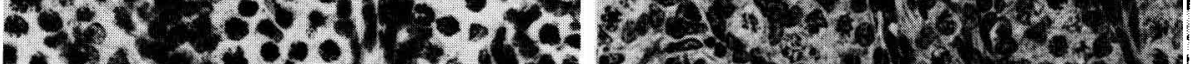

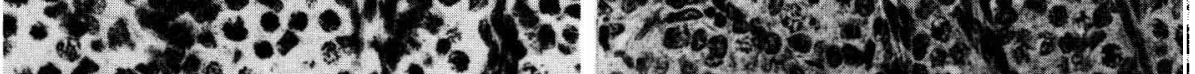

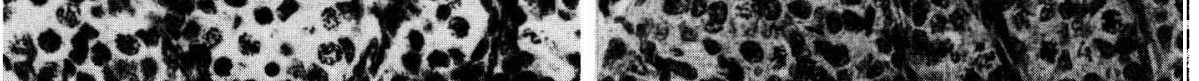

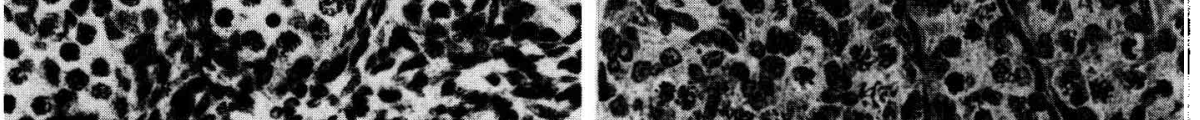

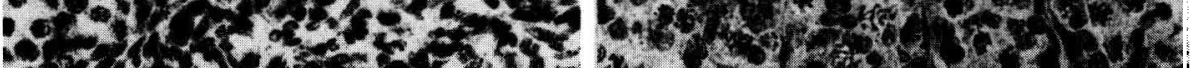

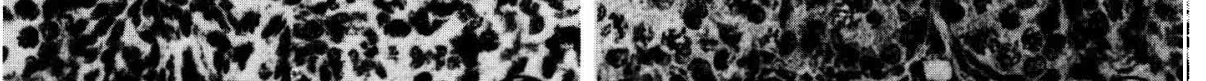

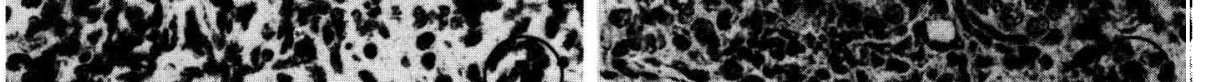

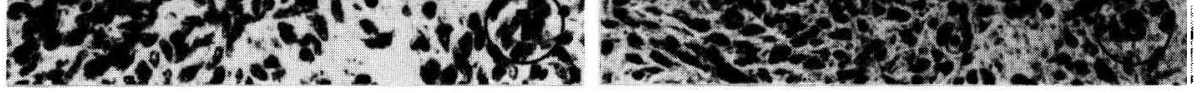
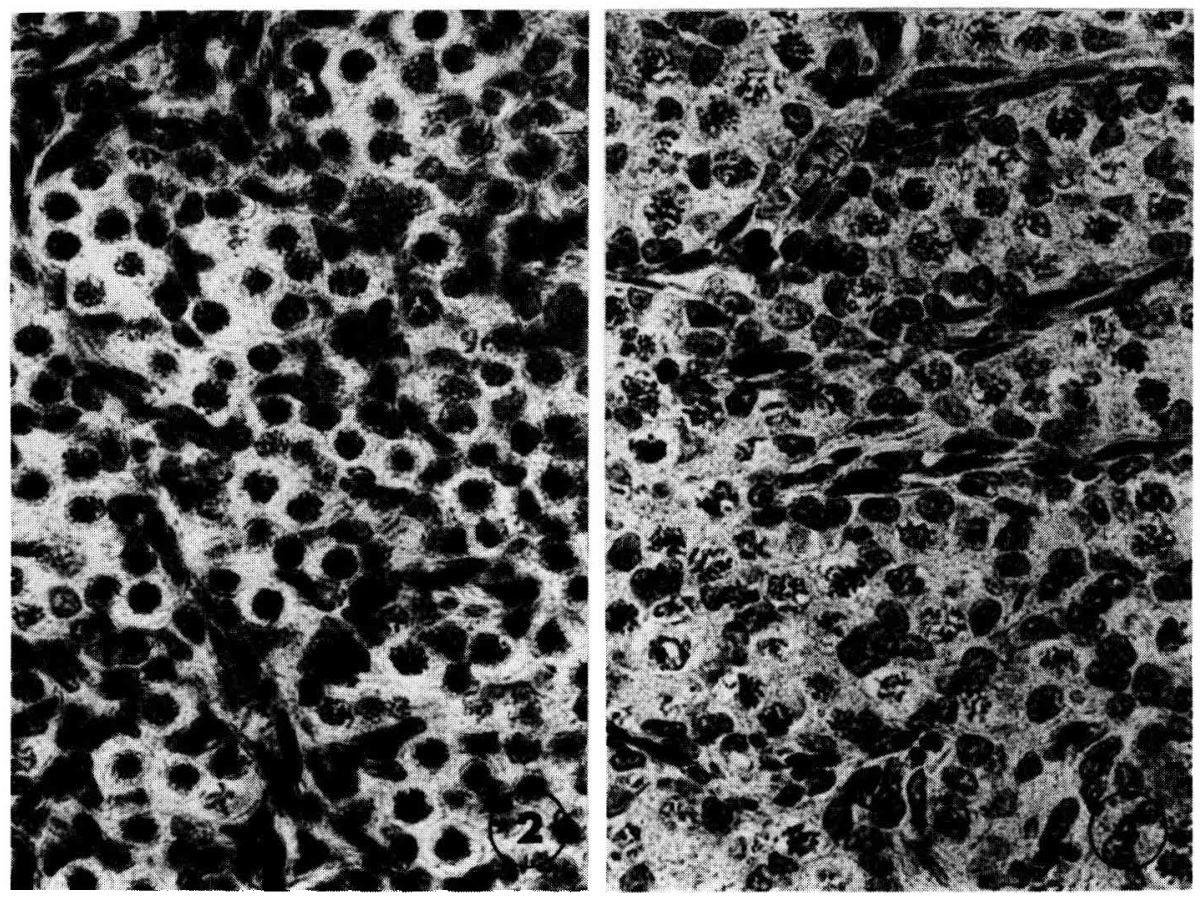

FIG. 1. - Fetal ovaries af day 21.1 and $2:$ Confrol (1) $\times 250$ and 2) 400), 3 and 4 : Fetus without pituitary (3) $\times 250$ and 4) $\times 400$ ). 
found LH activity in the 19-day rat fetus. However, Chowdhury and Steinberger (1976), using radioimmunological assay, detected no pituitary gonadotropins in female rat fetuses, while they were present in the blood of male fetuses at day 16 and in the pifuitary at day 17 . Noreover, these authors found no gonadotropin in the placental tissues.

The ovaries have been rarely studied in experiments using hypophysectomy or fetal decapitation.

Mauléon (1973), using cultures of ewe ovary, showed the importance of the environment in triggering meiosis; hypophyseal hormones did not play a large role. In fact, hypophysectomy only retarded the onset of meiosis by several days. The author attributed this delay to postoperative shock.

Challoner (1975), using cultures of fetal hamster ovary, reached similar conclusions showing that the environment, and mainly the ovarian stroma, played a major role in triggering meiosis. Adding gonadotropic hormones or maternal serum to the culture did not change the results.

That pituitary gonadotropins do not intervene in triggering meiosis in the female fetus was confirmed by our observations which show that the fetal rat ovary develops normally without the pituitary.

\section{Conclusion.}

Many factors in the mechanism of meiosis remain unknown. It appears, however, that the fetal pituitary does not intervene in its initiation; this was strongly suggested by the previous data of Mauléon and Challoner. However, the first author used hypophysectomy relatively late in fetal life, while the second employed in vitro techniques. Our observations on the total absence of pituitary formation clearly show that the fetal pituitary is not necessary for normal development of the fetal rat ovary, and particularly for triggering meiotic prophase.

Reçu en mai 1979.

Accepté en novembre 1979.

Résumé. Nous avons étudié les ovaires de fœtus de rats atteints d'agénésie hypophysaire provoqué par un inhibiteur de la synthèse du cholestérol administré à la mère. Ces gonades sont morphologiquement comparables à celles des foetus témoins et leurs ovocyłes sont en prophase méiotique. On conclut que l'hypophyse n'est pas nécessaire au développement normal de l'ovaire chez le fotus de rat.

\section{References}

BUGNON C., LENYS D., BLOCH B., FELLMANN D., 1976. Exploration cyto-immunologique sur coupes semi-fines des phénomènes de différenciation précoce de diverses populations cellulaires dans l'adénohypophyse fœtale humaine. C. R. Soc. Biol., 170, 5, 975-982.

BYSKOV A. G., 1974. Does the rete ovarii act as a trigger for the onset of meiosis ? Nature, 252, 396-397.

BYSKOV A. G., 1979. Regulation of meiosis in mammals. 4 th Workshop on the development and maturation of reproductive organs and functions (Oct. 1978). Ann. Biol. anim. Bioth. Biophys., 19, 1251-1261. 
CHALLONER S., 1975. Studies of oogenesis and follicular development in the golden hamster. 2. Initiation and control of meiosis in vitro. J. Anat., 119, 149-156.

CHOWDHURY M., STEINBERGER E., 1976. Pituitary and plasma levels of gonadotrophins in fœtal and newborn male and female rats. J. Endocr., 69, 381-384.

DUBOIS M., MAULÉON P., 1969. Mise en évidence par immunofluorescence des cellules à activité gonadotrope LH dans l'hypophyse du fœtus de Brebis. C. R. Acad. Sci. Paris, 269, 219-222.

LUCIANI J. M., DEVICTOR M., STAHL A., 1977. Preleptotene chromosome condensation in human fotal and neonatal testes. J. Embryol. exp. Morph., 38, 175-186.

MAULÉON P., 1973. Modification expérimentale de l'apparition et l'évolution de la prophase méiotique dans l'ovaire d'embryon de brebis. Ann. Biol. anim. Biochim. Biophys., 13, 89-109.

SANO M , SASAKI F., 1969. Embryonic development of the mouse anterior pituitary studied by light and electromicroscopy. Z. Anat. Entwickl. Gesch., 129, 195-222.

SCHECHTER J., 1971. The cytodifferenciation of the rabbit pars distalis : an electron microscopic study. Gen. comp. Endocrinol., 16, 1-20.

SETALO G., NAKANE P. K., 1972. Studies on the functional differenciation of cells in fetal anterior pituitary glands of rats with peroxidase-labeled antibody method. Anat. Rec., 172, 403-404. 